\title{
Value Addition to Watermelon Rind Through Jam Preparation
}

\author{
Mohaiminul Islam ${ }^{1}$, Md. Rasal-Monir ${ }^{1}$, Md. Belal Hossain ${ }^{2}$, Md. Kowser Hossain ${ }^{3}$, Samar Biswas ${ }^{1}$, \\ Md. Nazrul Islam ${ }^{1, *}$
}

${ }^{1}$ Department of Horticulture, Sher-e-Bangla Agricultural University, Dhaka, Bangladesh

${ }^{2}$ Department of Soil Science, Sher-e-Bangla Agricultural University, Dhaka, Bangladesh

${ }^{3}$ Institute of Seed Technology, Sher-e-Bangla Agricultural University, Dhaka, Bangladesh

Email address:

nislams2000@gmail.com (Md. Nazrul I.)

${ }^{*}$ Corresponding author

\section{To cite this article:}

Mohaiminul Islam, Md. Rasal-Monir, Md. Belal Hossain, Md. Kowser Hossain, Samar Biswas, Md. Nazrul Islam. Value Addition to Watermelon Rind Through Jam Preparation. Plant. Vol. 7, No. 1, 2019, pp. 5-12. doi: 10.11648/j.plant.20190701.12

Received: July 14, 2019; Accepted: August 5, 2019; Published: August 16, 2019

\begin{abstract}
An experiment was conducted at Postharvest Laboratory, Department of Horticulture, Sher-e-Bangla Agricultural University, Dhaka during February 2018 to December 2018 to add value to Watermelon rind and to study quality of watermelon rind jam as influenced by different concentration of rinds and sugar with flavors. This single factors experiment was consisted of sixteen treatments with three replications and laid out in CRD. The treatments were $\mathrm{T}_{1} \mathrm{~F}_{0}=50 \%$ rind $+50 \%$ sugar+no flavor; $\mathrm{T}_{1} \mathrm{~F}_{1}=50 \%$ rind $+50 \%$ sugar + strawberry flavor; $\mathrm{T}_{1} \mathrm{~F}_{2}=50 \%$ rind $+50 \%$ sugar + pineapple flavor; $\mathrm{T}_{1} \mathrm{~F}_{3}=50 \%$ rind $+50 \%$ sugar+vanila flavor; $\mathrm{T}_{2} \mathrm{~F}_{0}=80 \%$ rind $+20 \%$ sugar + no flavor; $\mathrm{T}_{2} \mathrm{~F}_{1}=80 \%$ rind $+20 \%$ sugar + strawberry flavor; $\mathrm{T}_{2} \mathrm{~F}_{2}=80 \%$ rind $+20 \%$ sugar+pineapple flavor; $\mathrm{T}_{2} \mathrm{~F}_{3}=80 \%$ rind $+20 \%$ sugar+vanila flavor; $\mathrm{T}_{3} \mathrm{~F}_{0}=60 \%$ rind $+40 \%$ sugar + no flavor; $\mathrm{T}_{3} \mathrm{~F}_{1}=60 \%$ rind $+40 \%$ sugar + strawberry flavor; $\mathrm{T}_{3} \mathrm{~F}_{2}=60 \%$ rind $+40 \%$ sugar + pineapple flavor; $\mathrm{T}_{3} \mathrm{~F}_{3}=60 \%$ rind $+40 \%$ sugar+vanila flavor; $\mathrm{T}_{4} \mathrm{~F}_{0}=40 \%$ rind $+60 \%$ sugar + no flavor; $\mathrm{T}_{4} \mathrm{~F}_{1}=40 \%$ rind $+60 \%$ sugar + strawberry flavor; $\mathrm{T}_{4} \mathrm{~F}_{2}=40 \%$ rind $+60 \%$ sugar+pineapple flavor; $\mathrm{T}_{4} \mathrm{~F}_{3}=40 \%$ rind $+60 \%$ sugar+vanila flavor. At first qualitative test was done for prepared jam. Then organolaptic test was done and last of all various chemical changes were determined with the storage period. $\mathrm{T}_{1} \mathrm{~F}_{1}$ was statistically best. The chemical analysis of $\mathrm{T}_{1} \mathrm{~F}_{1}$ jam was $\mathrm{pH}(3.80)$, TSS $(6.00 \%)$, TA (2.48\%), vitamin $\mathrm{C}(0.26 \mathrm{mg} / 100 \mathrm{~g})$. This suggested that $50 \%$ rind $+50 \%$ sugar and strawberry flavor was the promising formulation for the preparation of good quality of watermelon rind jam.
\end{abstract}

Keywords: Watermelon, Jam, Flavor, Rind

\section{Introduction}

Watermelon (Citrullus lanatus) is a tropical fruit widely consumed around the world. It belongs to the family of Cucurbitaceae, which is inherent to tropical Africa and a popular thirst-quencher during the hot summer weather. The Cucurbitaceae is a large plant family found mainly in the warmer parts of all continents. It consists of 119 genera with altogether 825 species [1]. Fruits of Cucurbitaceae have a considerable economic value. Total global production of watermelon was 108.9 million tons whereas India Production was 0.4 million tons in 2013 [2]. China is the largest producer of watermelon with 69.3 million tons of the total world production. Other major producing countries are Turkey, Iran, Brazil, the United States, Egypt, Russia and Mexico [3]. In Bangladesh, fruit cultivate area is about $137,557.08$ ha with the production of 45869188 tons in 2013-2014 [4]. Watermelon cultivation area is about $12,228.75$ ha with the production of 293103 metric tons [4]. Among the watermelon growing districts in 2013-2014 Patuakhali produces 4772 metric tons in 541.70 ha land [4]. Watermelon contains Vitamin C and A. Watermelon is also expectedly high in citrulline, amino acid and arginine (used in the urea cycle to remove ammoniacal from the body). Watermelon is the third most popular fruit in the world containing good quantity of nutrients [5]. 
Pigment extracted from watermelon acts as functional ingredient and can be incorporated into breakfast cereals, frozen dairy desserts, yoghurts, spreads, candy, carbonated beverages, confectionary, sauces and soups etc. [6]. Cucurbit seeds are source of food particularly protein and oil. The flesh which constitutes approximately $68 \%$ of the total weight, the rind approximately $30 \%$ and the seeds approximately $2 \%$. Watermelon rinds contained about 14.9 $35.7 \%$ protein (full fat free basis) and $35-59 \%$ on fat free basis [7]. The lipids were found to be rich in linoleic and oleic acids while the protein was rich in arginine, glutamic acid, aspartic acid and leucine amino acids in watermelon [8].

Almost one third of all fruits and vegetables produced in the world are not consumed as a result of postharvest losses, of which watermelon is no exception [9]. Huge losses of watermelon during storage $17 \%$ were caused by rot and more than $50 \%$ was due to physiological problems such as bruising and sun scorching [10]. Providing different postharvest facilities but shelf life of watermelon cannot be increased more than one month. Being a seasonal fruit, watermelon is available in season but in off season it is totally absent because of its short shelf life. Watermelon stored at 10 to $15^{\circ} \mathrm{C}$ with a relative humidity of $90 \%$ will be acceptable for up to 3 weeks. Watermelons held in below $24^{\circ} \mathrm{C}$ will have approximate shelf life up to 10 days. If temperatures are above $24^{\circ} \mathrm{C}$, shelf life will decline to 5 days. At temperatures between 0 and $7{ }^{\circ} \mathrm{C}$, watermelons are subject to chilling injury that may result in pitting, off-flavors, and color loss. To increase the shelf life as well as fulfill the demands of consumers, processed product can be alternate of fresh watermelon in off season. So the preservation of the process products and its year round availability is important to meet the demands of consumers.

There are different processed products of fruits such as juice, sauce, jam, jelly, leather etc. Among them jam is the oldest and most widely used preservation method in fruit process industries. It involves the reduction of as much water as possible from the fresh fruit to arrest enzymatic and microbial activities; hence, stopping deterioration [11].

Watermelon rind is one of the major solid wastes generated by several restaurants, cottage fruit juice producers and food industries in Bangladesh. Unfortunately, more than $90 \%$ of the rind is discarded indiscriminately into the environment thereby constituting environmental challenges. This waste rind is not presently being utilized for any value added processes due to limited research activities focusing on the possible conversion of the waste to other valuable products thereby making it available for dumping as solid waste. Chemically Watermelon rind contains large amount of water with promising levels of solid matters but devoid of high content of soluble sugar. These characteristics made it a viable candidate for the production of high quality jam. This novel use of Watermelon rind will among other things reduce the amount of the waste discarded, create more income for farmers, food processors and more importantly reduce environmental impacts of the waste. Therefore, the main focus of this research is to successfully document the physicochemical properties and sensory characteristics of jam made from Watermelon rind. Considering the nutritional quality of jam the present study was undertaken to produce quality jam from water melon rind and the physio-chemical properties of jam produced from water melon rind.

\section{Methodology}

The following methods were used for the present investigation. Those were:

a) Extraction of watermelon rinds

b) Processing of watermelon rinds

c) Preparation of watermelon jam

d) Pouring and storing of jam

e) Assessment of quality of jam

\subsection{Experimental Design}

The one factor experiment was laid out in the Completely Randomized Design (CRD) with three replications. The postharvest treatments were assigned randomly in each replication. The collected data on various parameters were statistically analyzed using data were analyzed using SPSS (1995) version 11.5 (SPSS inc., Chicago, IL, USA). One way ANOVA and completely randomized test were conducted to determine significance existing in the mean values at $\mathrm{P} \leq$ 0.05 .

\subsection{Experimental Materials}

Best quality watermelon fruits were used in this experiment. Healthy fruits with uniform size, shape, and maturity were purchased from the local market. Fruits were medium to large in size, about $4-5 \mathrm{~kg}$ in weight. The skin color was green to dark green and thick to highly thick, nonadhering and somewhat heavy; the seed was small but rinds were fleshy and thick. All fruits were thoroughly washed with tap water, followed by ringing with sterile distilled water.

\subsection{Collection of Watermelon Rinds, Preparation of Jam and Storing of Jam}

The following procedure was developed based on the preliminary trials to optimize the ingredients and methods. At first watermelon fruits were washed in clean water. The fruits were cut into small pieces (Figure 1) and rind was collected to remove pulp by knife. The rind was blended using a blender.

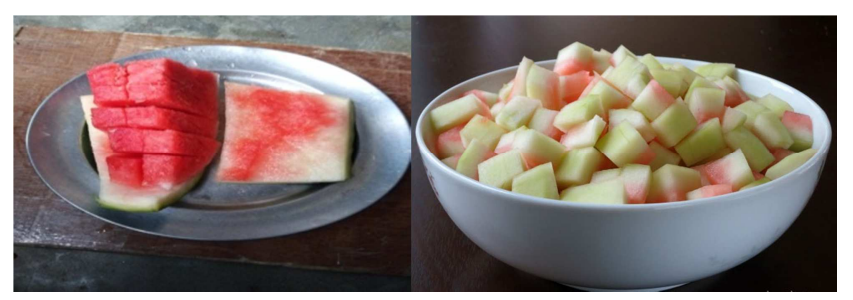

Figure 1. Pieces of watermelon rind. 
The blended watermelon rind (Figure 2) was low in brix. Mixtured of rind and sugar which kept at 45 minute in room temperature then $5 \mathrm{~g}$ pectin was added. The rind was increased by heating at 2000 watt for $1 \mathrm{hr}$ on an induction cooker until the brix became $60 \%$. Flavors were added at the last stage of cooking.

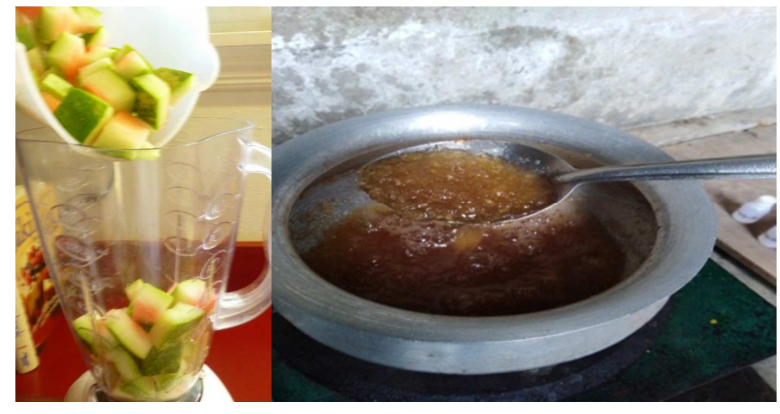

Figure 2. Blended Watermelon rind.

When jam was prepared then it was stored in glass jar (Figure 3). Jars were autoclaved before used. It was autoclaved for killing the harmful microorganism.

\subsection{Determination of Color}

The peel colour of the jam was determined using a Android Application Software namely "On Color Measure" (developed by Potato tree Soft, Version 3.0) equipped with an aim pointer. It provides the easiest way to store the information of each color detection. Color measurements were done at each face of jam.

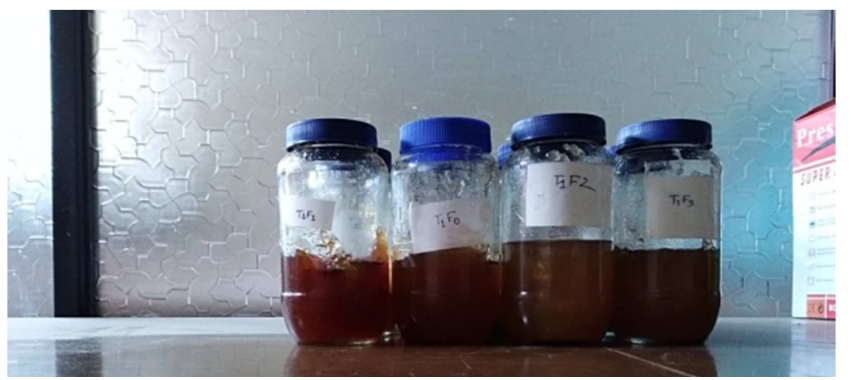

Figure 3. Watermelon rind jam stored in jar.

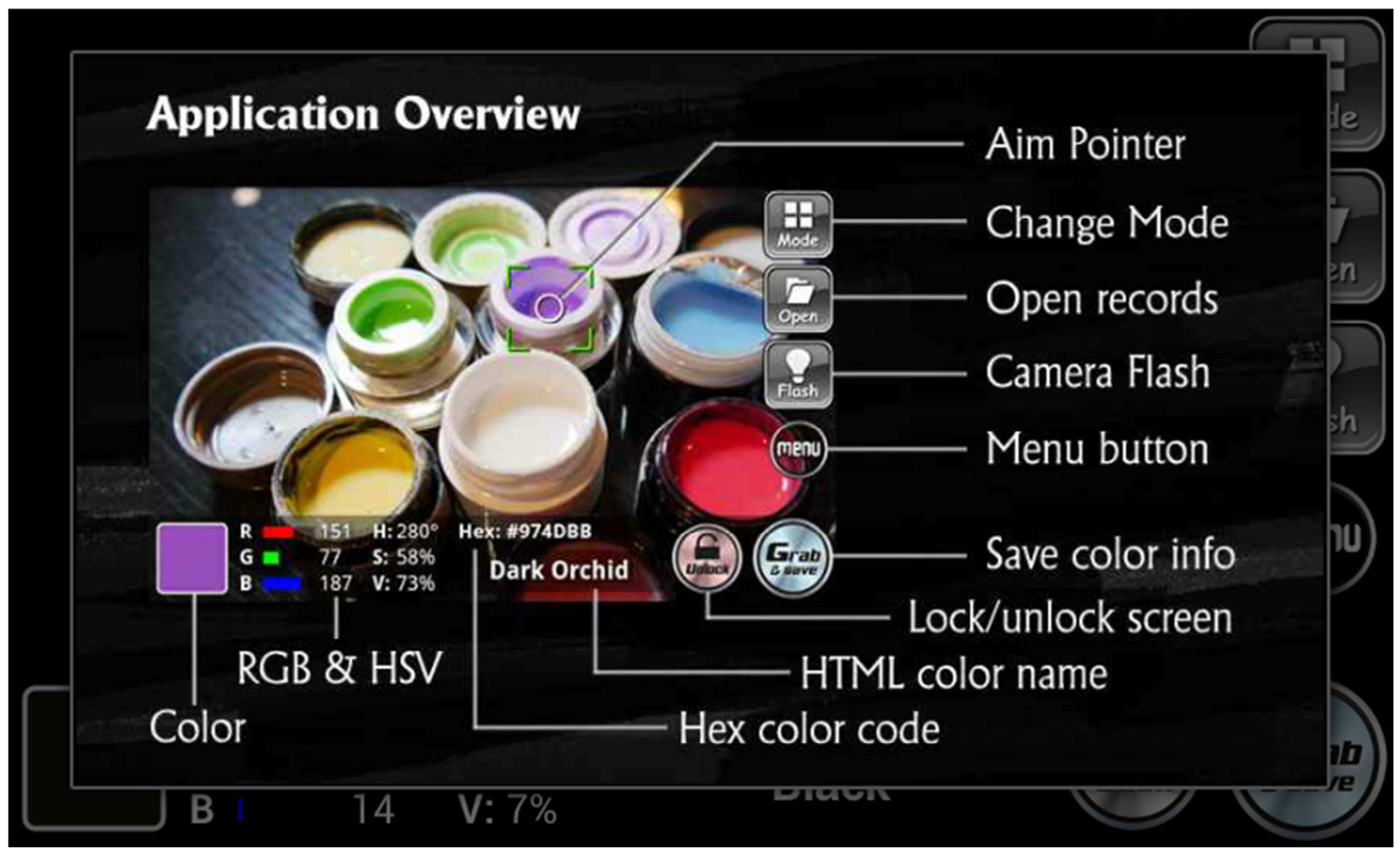

Figure 4. An application overview of the "On Color Measure" (source: potato tree software version 3 Google play apps).

Sample and a mean value was obtained. The leather color determination was expressed in chromaticity values of Red $\left(\mathrm{R}^{*}\right)$, Green $\left(\mathrm{G}^{*}\right)$ and Blue $\left(\mathrm{B}^{*}\right)$ (Plate 3.4) For measuring the color the camera was aimed at the target color point and clicked on crosshair pointer and moved it to any place on the screen. The dashboard displays the information of the color detected. Grab button was clicked to capture the screen image and saved all the detailed color information including RGB, HSV, color names, hex code and screen images.

\subsection{Determination of $\mathrm{pH}$}

The $\mathrm{pH}$ was determined using a glass electrode $\mathrm{pH}$ meter
(GLP 21, Crison, Barcelona, and EEC). Before being used, the $\mathrm{pH}$ meter was calibrated with buffers at $\mathrm{pH} 4.0$ followed by $\mathrm{pH}$ 7.0. After that, the glass electrode was placed into the filtrate to measure the $\mathrm{pH}$ and stabilized reading was recorded.

For accuracy of the reading, the glass electrode was washed after each reading with distilled water and wiped to dry with soft tissue paper.

\subsection{Determination of Tritratable Acidity}

The titratable acidity was estimated through the chemical analysis using watermelon rind jam. The titratable acidity of 
watermelon jam was determined according to Ranganna (1979). The following reagents were used for the determination of the titratable acidity. Standard $\mathrm{NaOH}$ solution $(0.1 \mathrm{~N}), 1 \%$ phenolphthalein solution and Extraction of the jam.

Ten gram of fresh watermelon jam sample was taken in a $500 \mathrm{ml}$ beaker and homogenized with distilled water in a blender (MX-798S, National, Malaysia). The blender materials were then filtered and transferred to a $500 \mathrm{ml}$ volumetric flask and the volume was made up to the mark with distilled water.

Five milliliters of the pulp solution was taken in a conical flask. Two to three drops of phenolphthalein indicator solution was added and then the conical flask was shaken vigorously. It was then titrated immediately with $0.01 \mathrm{~N}$ $\mathrm{NaOH}$ solution from a burette till the permanent pink color appeared. The volume of $\mathrm{NaOH}$ solution required for the titration was noted from burette reading and at the percent titratable acidity was calculated using the following formula:

$$
\text { Citric acid }(\%)=\frac{\text { Titre }(\mathrm{mL}) \times \mathrm{NaOH} \text { normality }(0.1 \mathrm{M}) \times \text { Vol.made up }(50 \mathrm{~mL}) \times \text { Citric acid eq.weight }(64 \mathrm{~g}) \times 100}{\text { Volume of sample for titrate }(5 \mathrm{~mL}) \times \text { Weight of sample taken }(10 \mathrm{~g}) \times 1000}
$$

\subsection{Determination of the Ascorbic Acid (Vitamin C) and Standardization of the Dye Solution}

The following reagents were used for the estimation of ascorbic acid content.

i) Three percent $(3 \%)$ Metaphosphoric acid $\left(\mathrm{HPO}_{3}\right)$

It was prepared by dissolving $30 \mathrm{~g}$ of $\mathrm{HPO}_{3}$ in $1000 \mathrm{ml}$ of distilled water.

ii) Standard ascorbic acid solution

Ten milligram of L-ascorbic acid solution was prepared by dissolving the ascorbic acid in $100 \mathrm{ml}$ of $3 \%$ metaphosphoric acid solution.

iii) Dye solution

It was prepared by dissolving $50 \mathrm{mg}$ of the sodium salt of 2, 6-dichlorophenol indophenol in approximately $50 \mathrm{ml}$ of hot distilled water containing $42 \mathrm{mg}$ of sodium bicarbonate. It was then cooled and diluted to $100 \mathrm{ml}$ with distilled water. The following steps were followed for the estimation of the ascorbic acid.

Ten milliliters $(10 \mathrm{ml})$ of the standard ascorbic acid solution was taken in a conical flask and $5 \mathrm{ml}$ of metaphosphoric acid $\mathrm{HPO}_{3}$ was added to it. A micro burette was filed with the dye solution. The content of the conical flask was titrated with the dye solution. The contents of the conical flask were titrated with the dye till the pink-colored end point appeared. The milliliters of dye solution required to complete the titration was recorded. The dye factor was calculated using the following formula:

$$
\text { Dye factor }=\frac{X}{\text { Titre }(\mathrm{mL})} \text { Here, } \mathrm{x}=0.5
$$

\subsection{Preparation of the Sample}

Five grams of the jam sample and $35 \mathrm{ml}$ of $3 \%$ metaphosphoric acid solution was taken in a blender and homogenized for 2 minutes. After blending it was filtered and centrifuged at about $2000 \mathrm{ppm}$ for 5 minutes. The supernatant homogenized liquid was transferred to a $50 \mathrm{ml}$ volumetric flask and the volume was made up with $3 \%$ metaphosphoric acid.

Ten milliliters of the aliquot was taken in a conical flask and titrated with dye solution. Then the ascorbic acid content of the samples was calculated using the following formula:

$$
\text { Ascorbic acid }\left(\mathrm{mg} 100 \mathrm{~g}^{-1}\right)=\frac{\text { Titre }(\mathrm{mL}) \times \text { dye factor }(0.081) \times \text { vol.made up }(50 \mathrm{~mL}) \times 100}{\text { Aliquot used for estimation }(5 \mathrm{~mL}) \times \text { sample weight }(10 \mathrm{~g})}
$$

\subsection{Determination of Soluble Solid Concentration}

The total soluble solids concentration of the jam was determined using a digital refractometer (Model N-1 $\alpha$, Atago, Japan). The remaining of the filtrated juice from TA determination was used to measure the SSC of the pulp. Before measurement, the refractometer was calibrated with distilled water to give a $0 \%$ reading. About 1-2 drops of the filtrate was placed on the prism glass of the refractometer to obtain the $\%$ SSC reading. The readings were multiplied by dilution factor to obtain the original $\%$ SSC of the pulp tissues. Since differences in sample temperature could affect the measurement of SSC (Boourne, 1982), each of the reading was standardized to a temperature of $20^{\circ} \mathrm{C}$ by adding $0.28 \%$ to obtain $\% \mathrm{SSC}$ at $27^{\circ} \mathrm{C}$.

\subsection{Sensory Evaluation of Jam}

An interview schedule was used for the sensory evaluation of the jam. Each panel list was asked to taste 16 treatments of jam. Each panel list was asked the five quality (attributes) questions and one question about their overall preference for the sample. Attributes selected for jam was overall appearance, texture (perception, stickiness and chewiness) sweetness, chewiness, flavor and overall acceptability of the sample. A 5-point hedonic scale was used. Therefore, the respondents answers were coded 1-5 with 7 being 'like extremely' and 1 being 'dislike extremely'. Three further questions were asked to assess whether the respondents liked the fruit leathers and sauce they had tasted. If they would buy the product and which they liked the best.

\section{Results and Discussion}

\subsection{Composition of the Fresh Watermelon}

The fresh watermelon had $95 \%$ moisture on the fresh weight. The $\mathrm{pH}$, total soluble solids (TSS), Tritratable acidity, total sugar and reducing sugar are presented in table 1. 
Table 1. Composition of the fresh watermelon used in the study.

\begin{tabular}{ll}
\hline Constituents of watermelon & Quantity \\
\hline 1. Moisture & $95 \%$ \\
2. $\mathrm{pH}$ & 5.01 \\
3. Total soluble solids & $15 \%$ \\
4. Tritratable acidity (citric Acid) & $3.12 \%$ \\
5. Total sugar & $12.02 \%$ \\
6. Reducing sugar & $5.52 \mathrm{~g}$ \\
\hline
\end{tabular}

The results of those experiments are presented and discussed separately under different titles.

\subsection{Color of Jam}

Color is one of the most important criteria of quality of watermelon. The changes of outer color of jam were monitored by measuring the value of Red (R), Green $(\mathrm{G})$ and Blue (B). Values are presented in the Figure 5. At the treatment-1, RGB\% was 50, 6 and 0 respectively. The green (G) color content was highest at the $\mathrm{T}_{1} \mathrm{~F}_{1}(50 \%$ rind $+50 \%$ sugar+strawberry flavor) $\operatorname{RGB} \%(55,7,0)$ and lowest at the $\mathrm{T}_{4} \mathrm{~F}_{3}(40 \%$ rind $+60 \%$ sugar+vanila flavor) $\mathrm{RGB} \%(38,2,0)$.

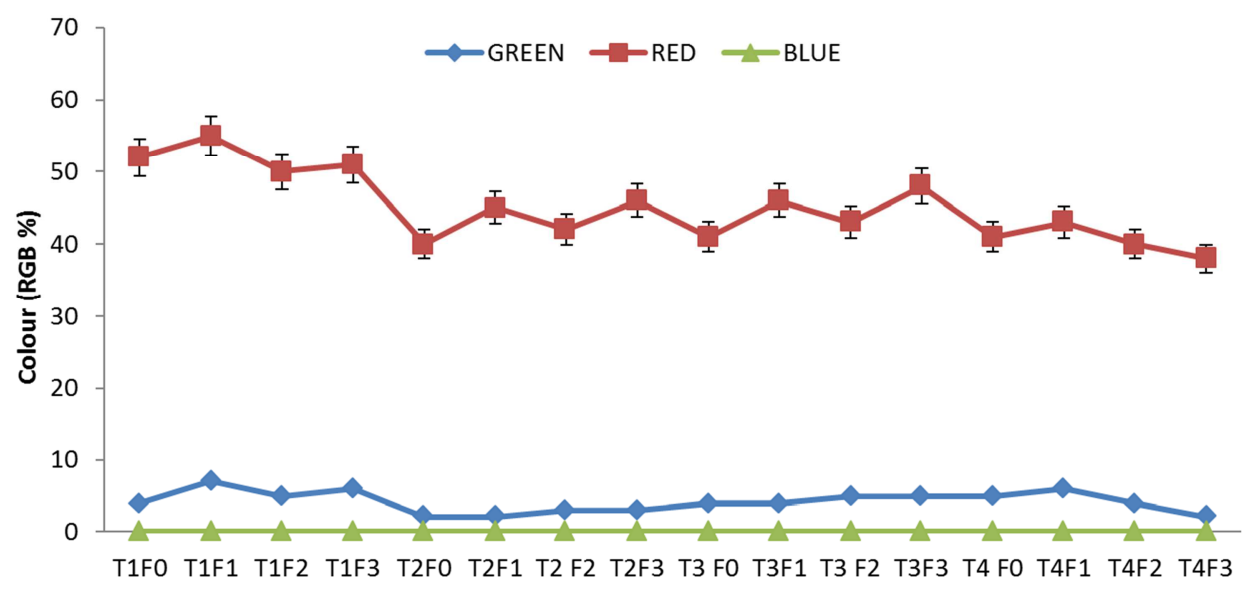

Figure 5. $R G B \%$ of watermelon jam at different treatments.

There was no significant difference regarding the changes in $\mathrm{R}$ and $\mathrm{B}$ values among the treatments. Blue color values was absent due to the induce heat during

\subsection{Effect of Different Concentration of Rinds and Sugar with Flavors for $\mathrm{pH}$}

The $\mathrm{pH}$ of jam at different treatments varied significantly which was given below (Table 2). During storage there was gradually increase and decrease of $\mathrm{pH}$ value of jam. The change was occurred after 30 to 90 days of storage time. At first the highest $\mathrm{pH}$ value (4.46) was found in $\mathrm{T}_{1} \mathrm{~F}_{1}$ and lowest $\mathrm{pH}$ value (4.09) was found in $\mathrm{T}_{3} \mathrm{~F}_{3}$.

Table 2. Effect of different concentration of rinds and sugar with flavors for $\mathrm{pH}$.

\begin{tabular}{|c|c|c|c|c|}
\hline \multirow{2}{*}{ Treatments } & \multicolumn{4}{|c|}{ pH at different days after storage } \\
\hline & $\mathbf{0}$ days & 30 days & 60 days & 90 days \\
\hline $\mathrm{T}_{1} \mathrm{~F}_{0}$ & $4.40 \pm .117^{\mathrm{ab}}$ & $4.07 \pm .133^{\mathrm{cd}}$ & $4.20 \pm .117^{\mathrm{d}}$ & $4.10 \pm .116^{\mathrm{d}}$ \\
\hline $\mathrm{T}_{1} \mathrm{~F}_{1}$ & $4.46 \pm .115^{\mathrm{a}}$ & $4.43 \pm .140^{\mathrm{a}}$ & $4.42 \pm .115^{\mathrm{ab}}$ & $4.40 \pm .115^{\mathrm{a}}$ \\
\hline $\mathrm{T}_{1} \mathrm{~F}_{2}$ & $4.00 \pm .115^{\mathrm{bc}}$ & $3.80 \pm .115^{\text {bc }}$ & $4.00 \pm .116^{\mathrm{d}}$ & $3.90 \pm .114^{\mathrm{bd}}$ \\
\hline $\mathrm{T}_{1} \mathrm{~F}_{3}$ & $4.20 \pm .115^{\mathrm{bc}}$ & $3.93 \pm .143^{\mathrm{cd}}$ & $3.90 \pm .117^{\mathrm{cd}}$ & $3.90 \pm .114^{\text {bd }}$ \\
\hline $\mathrm{T}_{2} \mathrm{~F}_{0}$ & $4.20 \pm .115^{\mathrm{bc}}$ & $4.00 \pm .115^{\mathrm{bc}}$ & $4.50 \pm .115^{\mathrm{a}}$ & $4.20 \pm .115^{\mathrm{bc}}$ \\
\hline $\mathrm{T}_{2} \mathrm{~F}_{1}$ & $4.20 \pm .114^{\mathrm{b}}$ & $3.90 \pm .117^{\mathrm{cd}}$ & $4.00 \pm .115^{\mathrm{b}}$ & $4.00 \pm .115^{\mathrm{c}}$ \\
\hline $\mathrm{T}_{2} \mathrm{~F}_{3}$ & $4.20 \pm .114^{\mathrm{b}}$ & $4.00 \pm .114^{\text {bd }}$ & $4.00 \pm .114^{\mathrm{b}}$ & $4.00 \pm .114^{\mathrm{bd}}$ \\
\hline $\mathrm{T}_{3} \mathrm{~F}_{0}$ & $4.40 \pm .114^{\mathrm{b}}$ & $4.20 \pm .115^{\mathrm{bc}}$ & $4.30 \pm .115^{\mathrm{bc}}$ & $4.00 \pm .117^{\mathrm{c}}$ \\
\hline $\mathrm{T}_{3} \mathrm{~F}_{1}$ & $4.23 \pm .115^{\mathrm{bc}}$ & $3.93 \pm .154^{\mathrm{abc}}$ & $4.10 \pm .117^{\mathrm{d}}$ & $3.90 \pm .114^{\mathrm{bd}}$ \\
\hline $\mathrm{T}_{3} \mathrm{~F}_{2}$ & $4.10 \pm .088^{d}$ & $3.90 \pm .057^{\mathrm{d}}$ & $4.00 \pm .117^{\mathrm{d}}$ & $4.00 \pm .115^{\mathrm{bc}}$ \\
\hline $\mathrm{T}_{3} \mathrm{~F}_{3}$ & $4.09 \pm .117^{\mathrm{d}}$ & $3.80 \pm .115^{\text {bd }}$ & $3.90 \pm .117^{\text {bd }}$ & $3.83 \pm .088^{\mathrm{d}}$ \\
\hline $\mathrm{T}_{4} \mathrm{~F}_{0}$ & $4.20 \pm .114^{\mathrm{b}}$ & $3.90 \pm .116^{\mathrm{c}}$ & $4.00 \pm .117^{\mathrm{d}}$ & $3.80 \pm .117^{\mathrm{d}}$ \\
\hline $\mathrm{T}_{4} \mathrm{~F}_{1}$ & $4.20 \pm .147^{\mathrm{bd}}$ & $4.00 \pm .115^{\text {bc }}$ & $4.20 \pm .115^{\text {bc }}$ & $4.30 \pm .114^{\mathrm{bd}}$ \\
\hline Level of Significance & $*$ & $*$ & $*$ & $*$ \\
\hline
\end{tabular}

Means in each column followed by the same letter ( $\mathrm{s}$ ) are significantly different at $\mathrm{P} \leq 0.05$ According to Duncan's Multiple Range Test

After 90 days the highest $\mathrm{pH}$ value (4.40) was found in $\mathrm{T}_{1} \mathrm{~F}_{1}$ and lowest $\mathrm{pH}$ value (3.80) was found in $\mathrm{T}_{4} \mathrm{~F}_{0}$ that was gradually decreased. The $\mathrm{pH}$ value was decreased due to the increased of acidity during storage of time. The same result was found Shahjahan et al., [12] noted that the acidity of mango was decreased gradually at the time of storage. 


\subsection{Total Soluble Solids Concentration}

The total soluble solids concentration of jam at different treatments varied significantly which was given below Table 3. It was significant $(\mathrm{P} \leq 0.05)$. During storage there was gradually increase TSS value of jam. The change was occurred after 30 to 90 days of storage time. At first the highest TSS value $(6.50 \%)$ was found in $\mathrm{T}_{3} \mathrm{~F}_{1}$ and the lowest value (1.90) of TSS was found in $\mathrm{T}_{2} \mathrm{~F}_{2}$. After 30 days the TSS value was increased and the highest value $(7.50 \%)$ of TSS was found in $\mathrm{T}_{4} \mathrm{~F}_{0}$ and the lowest value $(2.95 \%)$ of TSS was found in $\mathrm{T}_{2} \mathrm{~F}_{0}$. The TSS value was gradually increased at 90 days and the highest value (7.00) of TSS was found in $\mathrm{T}_{3} \mathrm{~F}_{1}$ and the lowest value (3.00) of TSS was found in $\mathrm{T}_{2} \mathrm{~F}_{2}$.

Table 3. Effect of different concentration of rinds and sugar with flavors for Total soluble solids.

\begin{tabular}{|c|c|c|c|c|}
\hline \multirow{2}{*}{ Treatments } & \multicolumn{4}{|c|}{ Total soluble solids\% at different days after storage } \\
\hline & 0 day & 30 days & 60 days & 90 days \\
\hline $\mathrm{T}_{1} \mathrm{~F}_{0}$ & $3.80 \pm .115^{\mathrm{a}}$ & $5.50 \pm .115^{\mathrm{a}}$ & $5.50 \pm .117^{\mathrm{c}}$ & $5.50 \pm .115^{\mathrm{a}}$ \\
\hline $\mathrm{T}_{1} \mathrm{~F}_{1}$ & $3.80 \pm .115^{\mathrm{a}}$ & $5.50 \pm .115^{\mathrm{a}}$ & $6.00 \pm .115^{\mathrm{a}}$ & $6.00 \pm .114^{\mathrm{b}}$ \\
\hline $\mathrm{T}_{1} \mathrm{~F}_{2}$ & $3.60 \pm .154^{\mathrm{b}}$ & $6.00 \pm .115^{\mathrm{b}}$ & $5.00 \pm .114^{\mathrm{b}}$ & $5.50 \pm .117^{\mathrm{d}}$ \\
\hline $\mathrm{T}_{1} \mathrm{~F}_{3}$ & $3.70 \pm .117^{\mathrm{c}}$ & $6.00 \pm .115^{\mathrm{b}}$ & $5.50 \pm .117^{\mathrm{b}}$ & $5.00 \pm .115^{\mathrm{cd}}$ \\
\hline $\mathrm{T}_{2} \mathrm{~F}_{0}$ & $2.20 \pm .114^{\mathrm{b}}$ & $2.95 \pm .088^{\mathrm{b}}$ & $3.00 \pm .117^{\mathrm{c}}$ & $3.50 \pm .115^{\mathrm{bc}}$ \\
\hline $\mathrm{T}_{2} \mathrm{~F}_{1}$ & $2.03 \pm .117^{\mathrm{c}}$ & $3.50 \pm .088^{\mathrm{b}}$ & $3.20 \pm .115^{\mathrm{bc}}$ & $3.20 \pm .117^{\mathrm{b}}$ \\
\hline $\mathrm{T}_{2} \mathrm{~F}_{3}$ & $2.50 \pm .088^{\mathrm{bd}}$ & $3.50 \pm .115^{\mathrm{b}}$ & $2.50 \pm .088^{\mathrm{d}}$ & $3.17 \pm .081^{\mathrm{b}}$ \\
\hline $\mathrm{T}_{3} \mathrm{~F}_{0}$ & $3.90 \pm .088^{\mathrm{b}}$ & $5.50 \pm .114^{\mathrm{b}}$ & $5.00 \pm .088^{\mathrm{b}}$ & $5.00 \pm .088^{\mathrm{b}}$ \\
\hline $\mathrm{T}_{3} \mathrm{~F}_{1}$ & $6.50 \pm .088^{\mathrm{b}}$ & $6.50 \pm .114^{\mathrm{b}}$ & $7.00 \pm .088^{\mathrm{b}}$ & $7.00 \pm .088^{\mathrm{b}}$ \\
\hline $\mathrm{T}_{3} \mathrm{~F}_{2}$ & $4.53 \pm .088^{\mathrm{b}}$ & $5.00 \pm .114^{\mathrm{b}}$ & $5.00 \pm .088^{\mathrm{c}}$ & $5.00 \pm .088^{\mathrm{b}}$ \\
\hline $\mathrm{T}_{3} \mathrm{~F}_{3}$ & $4.00 \pm .114^{\mathrm{b}}$ & $5.00 \pm .114^{\mathrm{b}}$ & $4.00 \pm .088^{\mathrm{d}}$ & $5.00 \pm .088^{\mathrm{b}}$ \\
\hline $\mathrm{T}_{4} \mathrm{~F}_{0}$ & $5.80 \pm .114^{\mathrm{b}}$ & $7.20 \pm .088^{\mathrm{b}}$ & $6.00 \pm .115^{\mathrm{bc}}$ & $6.00 \pm .081^{\mathrm{bc}}$ \\
\hline $\mathrm{T}_{4} \mathrm{~F}_{1}$ & $4.00 \pm .114^{\mathrm{b}}$ & $5.00 \pm .088^{\mathrm{b}}$ & $4.50 \pm .114^{\mathrm{b}}$ & $4.50 \pm .115^{b}$ \\
\hline $\mathrm{T}_{4} \mathrm{~F}_{3}$ & $5.00 \pm .114^{\mathrm{b}}$ & $7.00 \pm .114^{\mathrm{b}}$ & $6.50 \pm .117^{\mathrm{d}}$ & $6.00 \pm .115^{\mathrm{d}}$ \\
\hline Level of Significance & $*$ & $*$ & $*$ & $*$ \\
\hline
\end{tabular}

Means in each column followed by the same letter (s) are significantly different at $\mathrm{P} \leq 0.05$ according to Duncan's Multiple Range Test

\subsection{Titratable Acidity}

The titratable acidity of jam at different treatments varied significantly $(\mathrm{P} \leq 0.05)$ which was given below (Table 4$)$. During storage there was gradually decrease TA value of jam. The change was occurred after 30 to 90 days of storage time. At first the highest TA value $(2.60 \%)$ was found in $\mathrm{T}_{1} \mathrm{~F}_{1}$ and the lowest value (1.64\%) of TA was found in $\mathrm{T}_{3} \mathrm{~F}_{0}$. After 30 days the TA value was decreased and the highest value $(2.56 \%)$ of TSS was found in $\mathrm{T}_{1} \mathrm{~F}_{1}$ and the lowest value (1.44\%) of TA was found in $\mathrm{T}_{3} \mathrm{~F}_{1}$ due to decrease of acidity. After 60 days the
TA value was decreased and the highest value $(2.50 \%)$ of TSS was found in $\mathrm{T}_{1} \mathrm{~F}_{1}$ and the lowest value $(1.52 \%)$ of $\mathrm{TA}$ was found in $\mathrm{T}_{3} \mathrm{~F}_{0}$. The $\mathrm{TA}$ value was gradually decreased at 90 days and the highest value $(2.48 \%)$ of TA was found in $\mathrm{T}_{1} \mathrm{~F}_{1}$ and also the lowest value $(1.45 \%)$ was found $\mathrm{T}_{3} \mathrm{~F}_{0}$.

It was happened for the lower acidity. Among all the combined treatment and flavors $T_{1} F_{1}$ showed the best value during storage of time. Titratable acidity is also importance for the maintenance of quality so $T_{1} F_{1}$ indicated the best quality during storage of time for the low decreased of TA.

Table 4. Effect of different concentration of rinds and sugar with flavors for Titratable acidity.

\begin{tabular}{|c|c|c|c|c|}
\hline \multirow{2}{*}{ Treatments $\times$ flavors } & \multicolumn{4}{|c|}{ Titratable acidity\% at different days after storage } \\
\hline & 0 day & 30 days & 60 days & 90 days \\
\hline $\mathrm{T}_{1} \mathrm{~F}_{0}$ & $2.56 \pm .012^{\mathrm{bc}}$ & $2.56 \pm .011^{\mathrm{bc}}$ & $2.30 \pm .015^{\mathrm{c}}$ & $2.30 \pm .011^{\mathrm{c}}$ \\
\hline $\mathrm{T}_{1} \mathrm{~F}_{1}$ & $2.60 \pm .012^{\mathrm{b}}$ & $2.56 \pm .014^{\mathrm{bc}}$ & $2.50 \pm .013^{\mathrm{d}}$ & $2.48 \pm .011^{\mathrm{b}}$ \\
\hline $\mathrm{T}_{1} \mathrm{~F}_{2}$ & $2.30 \pm .011^{\mathrm{d}}$ & $2.29 \pm .011^{\mathrm{b}}$ & $2.23 \pm .013^{\mathrm{d}}$ & $2.20 \pm .011^{\mathrm{d}}$ \\
\hline $\mathrm{T}_{1} \mathrm{~F}_{3}$ & $2.43 \pm .011^{\mathrm{b}}$ & $2.30 \pm .011^{\mathrm{d}}$ & $2.30 \pm .013^{\mathrm{c}}$ & $2.30 \pm .011^{\mathrm{d}}$ \\
\hline $\mathrm{T}_{2} \mathrm{~F}_{0}$ & $2.30 \pm .012^{\mathrm{b}}$ & $2.18 \pm .012^{\mathrm{b}}$ & $2.30 \pm .014^{\mathrm{c}}$ & $2.30 \pm .011^{\mathrm{c}}$ \\
\hline $\mathrm{T}_{2} \mathrm{~F}_{1}$ & $2.56 \pm .014^{\mathrm{b}}$ & $2.43 \pm .014^{\mathrm{b}}$ & $2.30 \pm .014^{\mathrm{d}}$ & $2.30 \pm .014^{\mathrm{d}}$ \\
\hline $\mathrm{T}_{2} \mathrm{~F}_{3}$ & $2.43 \pm .014^{\mathrm{d}}$ & $2.41 \pm .014^{\mathrm{c}}$ & $2.40 \pm .014^{\mathrm{d}}$ & $2.39 \pm .011^{\mathrm{b}}$ \\
\hline $\mathrm{T}_{3} \mathrm{~F}_{0}$ & $1.64 \pm .014^{\mathrm{c}}$ & $1.56 \pm .014^{\mathrm{c}}$ & $1.52 \pm .014^{\mathrm{d}}$ & $1.45 \pm .011^{\mathrm{b}}$ \\
\hline $\mathrm{T}_{3} \mathrm{~F}_{1}$ & $1.79 \pm .012^{\mathrm{d}}$ & $1.44 \pm .014^{\mathrm{c}}$ & $2.18 \pm .014^{\mathrm{d}}$ & $2.30 \pm .011^{\mathrm{b}}$ \\
\hline $\mathrm{T}_{3} \mathrm{~F}_{2}$ & $1.79 \pm .011^{\mathrm{d}}$ & $1.66 \pm .011^{\mathrm{c}}$ & $1.66 \pm .014^{\mathrm{b}}$ & $1.52 \pm .011^{\mathrm{b}}$ \\
\hline $\mathrm{T}_{3} \mathrm{~F}_{3}$ & $1.66 \pm .011^{\mathrm{d}}$ & $1.66 \pm .011^{\mathrm{d}}$ & $1.59 \pm .011^{\mathrm{c}}$ & $1.55 \pm .011^{\mathrm{b}}$ \\
\hline $\mathrm{T}_{4} \mathrm{~F}_{0}$ & $2.18 \pm .012^{\mathrm{b}}$ & $1.92 \pm .012^{\mathrm{d}}$ & $1.92 \pm .011^{\mathrm{d}}$ & $1.75 \pm .012^{\mathrm{d}}$ \\
\hline $\mathrm{T}_{4} \mathrm{~F}_{1}$ & $2.30 \pm .011^{\mathrm{d}}$ & $2.18 \pm .011^{\mathrm{d}}$ & $2.18 \pm .015^{\mathrm{d}}$ & $2.15 \pm .015^{\mathrm{d}}$ \\
\hline $\mathrm{T}_{4} \mathrm{~F}_{2}$ & $2.30 \pm .011^{\mathrm{c}}$ & $2.18 \pm .011^{\mathrm{b}}$ & $2.18 \pm .015^{\mathrm{d}}$ & $2.13 \pm .011^{\mathrm{d}}$ \\
\hline Level of Significance & $*$ & $*$ & $*$ & $*$ \\
\hline
\end{tabular}

Means in each column followed by the same letter (s) are significantly different at $\mathrm{P} \leq 0.05$ according to Duncan's Multiple Range Test 


\subsection{Vitamin C}

The vitamin $\mathrm{C}$ of jam at different treatments varied significantly $(\mathrm{P} \leq 0.05)$ which was given below (Table 4$)$. During storage there was gradually decrease vitamin $\mathrm{C}$ value of jam. The change was occurred after 30 to 90 days of storage time. At first the highest value $(0.35 \mathrm{mg} / 100 \mathrm{~g})$ of vitamin $C$ was found in $T_{1} F_{1}$ and the lowest value $(0.18 \mathrm{mg} / 100 \mathrm{~g})$ of vitamin $\mathrm{C}$ was found in $\mathrm{T}_{4} \mathrm{~F}_{3}$. After 30 days the vitamin $\mathrm{C}$ value was decreased and the highest value $(0.30 \mathrm{mg} / 100 \mathrm{~g})$ of vitamin $C$ was found in $T_{1} F_{1}$ and the lowest value $(0.17 \mathrm{mg} / 100 \mathrm{~g})$ of vitamin $\mathrm{C}$ was found in $\mathrm{T}_{4} \mathrm{~F}_{3}$. After 60 days the vitamin $\mathrm{C}$ value was decreased and the highest value $(0.27 \mathrm{mg} / 100 \mathrm{~g})$ of vitamin $\mathrm{C}$ was found in $\mathrm{T}_{1} \mathrm{~F}_{1}$ and the lowest value $(0.16 \mathrm{mg} / 100 \mathrm{~g})$ of vitamin $\mathrm{C}$ was found in $\mathrm{T}_{4} \mathrm{~F}_{3}$. Vitamin $\mathrm{C}$ value was gradually decreased at 90 days and the highest value $(0.26 \mathrm{mg} / 100 \mathrm{~g})$ of vitamin $\mathrm{C}$ was found in $\mathrm{T}_{1} \mathrm{~F}_{1}$ and also the lowest value $(0.16 \mathrm{mg} / 100 \mathrm{~g})$ of vitamin $\mathrm{C}$ was found $\mathrm{T}_{4} \mathrm{~F}_{3}$.

However, loss of ascorbic acid content was comparatively lower during first month of storage. So it indicated that there was great change of vitamin $\mathrm{C}$ during storage and some treated jam was gradually small decrease and some showed higher decrease. Same value was found during storage of time. Among all the combined treatment with flavors $T_{1} F_{1}$ showed the best value during storage of time. Vitamin $\mathrm{C}$ is also importance for the maintains of quality of jam so $T_{1} F_{1}$ prepared jam had given the best quality of during storage of time for the low decreased of vitamin $\mathrm{C}$.

Table 5. Effect of different concentration of rinds and sugar with flavors for Vitamin C.

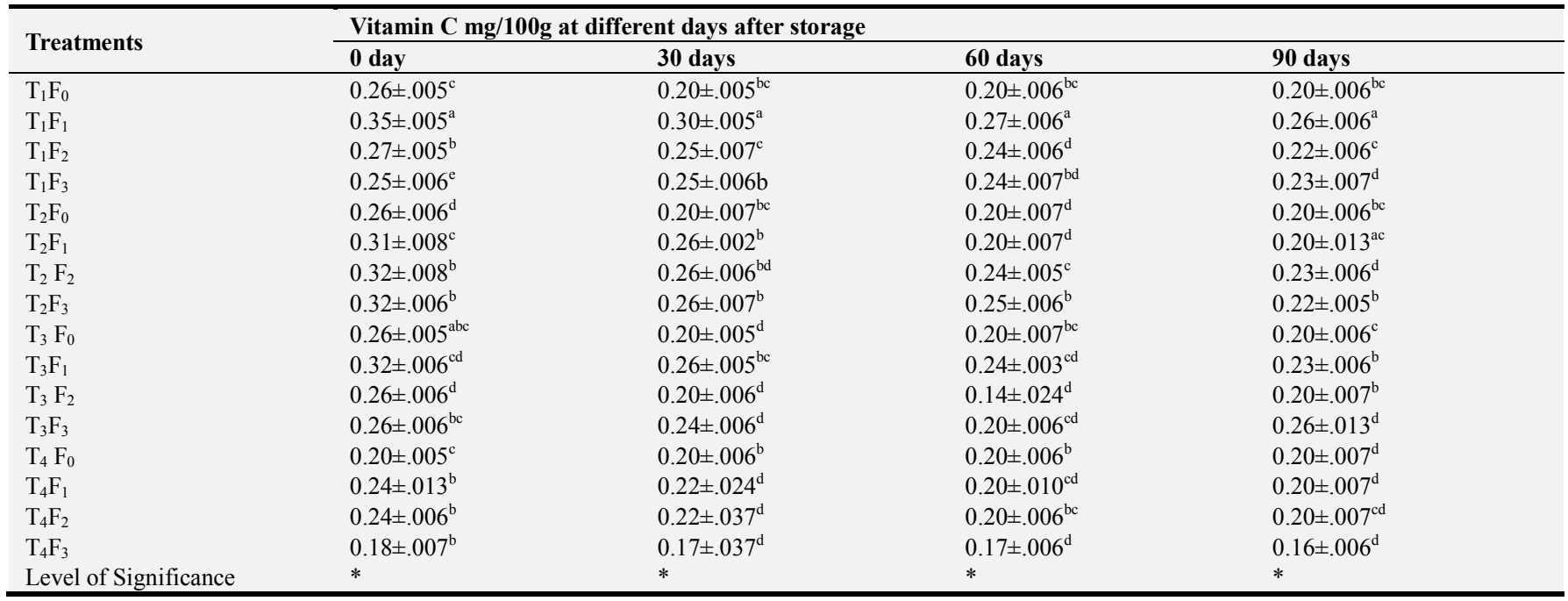

Means in each column followed by the same letter (s) are significantly different at $\mathrm{P} \leq 0.05$ according to Duncan's Multiple Range Test

\subsection{Sensory Evaluation}

The highest hedonic scale of appearance, texture, sweetness, and flavor point was recorded.

Table 6. Mean score for color, appearance, texture, sweetness, and flavor and for jam sample.

\begin{tabular}{|c|c|c|c|c|c|}
\hline Treatments & Taste & Flavor & Sweetness & Texture & Appearance \\
\hline T1F0 & 2.33 & 2.00 & 5.00 & 4.67 & 4.33 \\
\hline $\mathrm{T} 1 \mathrm{~F} 1$ & 5.00 & 4.00 & 5.00 & 4.67 & 4.67 \\
\hline $\mathrm{T} 1 \mathrm{~F} 2$ & 5.00 & 5.00 & 5.00 & 4.67 & 4.67 \\
\hline T1F3 & 4.00 & 4.00 & 5.00 & 4.67 & 4.00 \\
\hline $\mathrm{T} 2 \mathrm{~F} 0$ & 2.00 & 2.00 & 2.00 & 1.67 & 2.00 \\
\hline $\mathrm{T} 2 \mathrm{~F} 1$ & 3.67 & 4.00 & 2.00 & 2.00 & 2.33 \\
\hline $\mathrm{T} 2 \mathrm{~F} 2$ & 3.33 & 3.00 & 2.00 & 2.00 & 2.33 \\
\hline T3F0 & 2.33 & 2.00 & 3.00 & 3.00 & 3.00 \\
\hline $\mathrm{T} 3 \mathrm{~F} 1$ & 4.67 & 4.33 & 3.00 & 3.00 & 3.33 \\
\hline $\mathrm{T} 3 \mathrm{~F} 2$ & 4.33 & 5.00 & 3.00 & 3.00 & 3.33 \\
\hline T3F3 & 3.67 & 4.00 & 3.00 & 3.00 & 3.33 \\
\hline T4F0 & 2.33 & 2.33 & 3.67 & 2.67 & 4.67 \\
\hline T4F1 & 5.00 & 4.33 & 4.00 & 3.33 & 4.67 \\
\hline $\mathrm{T} 4 \mathrm{~F} 2$ & 4.00 & 5.00 & 4.00 & 3.00 & 4.33 \\
\hline $\mathrm{T} 4 \mathrm{~F} 3$ & 2.33 & 2.00 & 5.00 & 4.67 & 4.33 \\
\hline
\end{tabular}

Where, $1=$ extremely dislike; $2=$ dislike; $3=$ =medium; $4=$ like; $5=$ extremely like 
The recorded value was showed in table 6. The highest hedonic scale of taste, appearance, texture, sweetness, and flavor point was recorded with $\mathrm{T}_{1} \mathrm{~F}_{1}$. The lowest hedonic scale of appearance, texture, sweetness, and flavor point was recorded at $T_{2} F_{0}$. So it indicated that $T_{1} F_{1}$ prepared jam is good among all treated jam.

\section{Conclusion}

Form results we showed that the red $(\mathrm{R})$ colour was highest with $\mathrm{T}_{1} \mathrm{~F}_{1} \operatorname{RGB} \%(55,7,0)$ and lowest at the $\mathrm{T}_{4} \mathrm{~F}_{3}$ RGB\% $(38,2,0)$. The $\mathrm{pH}$ value was significantly high and after 90 days of storage the highest $\mathrm{pH}$ value (4.40) was found in $\mathrm{T}_{1} \mathrm{~F}_{1}$ and lowest $\mathrm{pH}$ value (3.80) was found in $\mathrm{T}_{4} \mathrm{~F}_{0}$ After 90 days of storage the highest value $(7.00 \%)$ of TSS was found in $\mathrm{T}_{3} \mathrm{~F}_{1}$ and the lowest value $(3.00 \%)$ of TSS was found in $\mathrm{T}_{2} \mathrm{~F}_{2}$. The TA value was gradually decreased at 90 days and the highest value $(2.48 \%)$ of TA was found in $\mathrm{T}_{1} \mathrm{~F}_{1}$ and also the lowest value $(1.45 \%)$ was found $\mathrm{T}_{3} \mathrm{~F}_{0}$. Vitamin $C$ value was gradually decreased at 90 days and the highest value $(0.26 \mathrm{mg} / 100 \mathrm{~g})$ of vitamin $\mathrm{C}$ was found in $\mathrm{T}_{1} \mathrm{~F}_{1}$ and also the lowest value $(0.16 \mathrm{mg} / 100 \mathrm{~g})$ of vitamin $\mathrm{C}$ was found $\mathrm{T}_{4} \mathrm{~F}_{3}$. The highest hedonic scale of taste, appearance, texture, sweetness, and flavor point was recorded with $\mathrm{T}_{1} \mathrm{~F}_{1}$. The lowest hedonic scale of appearance, texture, sweetness, and flavor point was recorded at $\mathrm{T}_{2} \mathrm{~F}_{0}$. So it indicated that $T_{1} F_{1}$ prepared jam was "Like very much" among all prepared jam.

In conclusion, the present study suggests that, $\mathrm{T}_{1} \mathrm{~F}_{1}(50 \%$ rind $+50 \%$ suga $r+$ strawberry flavor) prepared jam is the best quality among all jam. The physical, chemical and sensory qualities are better with $\mathrm{T}_{1} \mathrm{~F}_{1}$ than other treatments with flavors. So the quality of watermelon rind jam may be good up to 90 days by preparing $50 \%$ rind $+50 \%$ sugar + strawberry flavor. Therefore, to ensure the best quality of jam further research studies are necessary on fungal and bacterial growth.

\section{References}

[1] Schippers R. R. 2002. African indigenous vegetables. An over view of the cultivated species, revised version on CD ROM, Natural Resources International Limited, Aylesford, UK.

[2] FAO, 2016: http://www. FAO STAT3.fao.org

[3] FAO state 2005: http://www.faostat.fao.org

[4] BBS.(2014). All crops Summary 2013-14. Year book of Agricultural Statistics of Bangladesh. Bangladesh Bureau of Statistics. Statistics Division, Ministry of Planning, Government of the Peoples Republic of Bangladesh. pp. 115-18.

[5] Zhao P, Liu S, Zhu Z, Amanullah S, Davis AR 2013: Comparative transcriptome analysis of two contrasting watermelon genotypes during fruit development and ripening 12: 122-234.

[6] Olempska beer, ZS, RI, Merker, MD, Ditto 2006: Food processing enzymes from recombinant organism. 45 144-58.

[7] Del Valle V, H noz P, Guarda A. Galotto MJ 2005: Development of a cactus-mucilage edible coating (Opuntia ficus indica) and its application to extend strawberry (Fragaria ananassa) shelf-life. J. F. Che. 914 751-756.

[8] El-Ghaouth (1997). Biologically-based alternatives to synthetic fungicides for the control of postharvest diseases. Journal of Industrial Microbiology and Biotechnology 19 160-162.

[9] Kader, A 2005: Increasing food availability by reducing postharvest losses of fresh produce. Acta Horticulture 682 21692175 .

[10] Lamptey, S 2010: Postharvest losses in watermelon. A Dissertation Presented to the Crop Science Department, the College of Agriculture and Consumer Sciences, University of Ghana, Legon.

[11] Teshome, B. (2010). Effect of processing on some quality attributes of mango (Mangiferaindica) fruit leather [Electronic]. 146. Retrieved, Master of Science.

[12] Shahjahan M. S., Shell M. A., Zaman M. A. and Sakur 1994. Optimization of harvesting maturities for major mango cultivars in Bangladesh. Bd, J. Sci. Res., 13: 209-215. 